\title{
Chats perchés (2004) de Chris Marker: arte e política em Paris pelo olhar de um gato sorridente
}

\author{
Chris Marker's Chats perchés (2004): arts and politics in Paris under the \\ gaze of a grinning cat
}

\section{Miguel Angel Lomillos}

Professor adjunto da Universidade Federal do Maranhão (UFMA)

Submetido em 07 de Setembro de 2019 Aceito em 06 de Dezembro de 2019

\section{RESUMO}

O filme-ensaio de Chris Marker Chats perchés (2004) se articula em dois eixos guiados pela fala do autor enunciada em cartelas: a proliferação de grafites de gatos amarelos sorridentes nos muros e tetos da cidade e os numerosos protestos nas ruas. Toda essa excitação ocorreu na cidade de Paris durante os conturbados anos da campanha presidencial, guerra do Iraque e greve geral (2001-2003). 0 filme é analisado à luz dessas relações entre arte e política, do confronto com as imagens e sons que permeiam essa forma de filme-ensaio e das referências à obra do multifacetado autor francês.

PALAVRAS-CHAVE: Filme-ensaio; Espaço urbano; Arte da rua; Cidadania; Cinema digital.

\section{ABSTRACT}

Chris Marker's essay film The case of the grinning cat (Chats perchés, 2004) is articulated by two central concepts led by the author's commentary intertitles: the proliferation of a graffiti image of a grinning yellow cat over the walls and rooftops of the city and the numerous protests on the streets. All this excitement took place in the city of Paris along the turbulent period of presidential elections, the Iraq war and general strike (2001-2003). The film analysis is based on the relations between art and politics, confronting the peculiar images and sounds of this type of film essay and references to the oeuvre of this multifaceted French filmmaker.

KEYWORDS: Essay film; Urban space; Street art; Citizenship; Digital film.

Dossiê A Música e suas Determinações Materiais - https://revistaecopos.eco.ufrj.br/ 


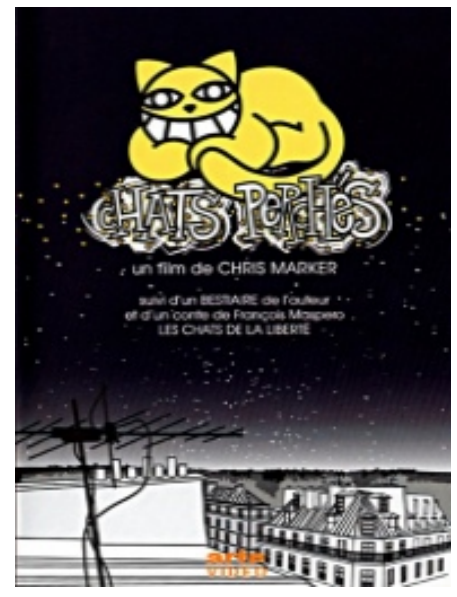

Ils ont insulté les vaches,

Ils ont insulté les gorilles,

Les poulets.

Ils ont insulté les veaux,

Ils ont insulté les oies, les serins,

Les couchons, les maqueraux

Les chameux,

Ils ont insulté les chiens.

Les chats,

Ils n'ont pas osé.

Jacques Prévert

\section{Um artista singular obcecado pelo tempo, a história e a memória}

O cinema nunca deixou de registrar e (re)configurar a experiência que lhe coube viver, inclusive a de seus momentos mais turbulentos. Segundo Casetti, o espetáculo do mundo que constitui o grande legado do cinema tem dois aspectos correlatos: por um lado, o cinema nos conectava ou nos devolvia à realidade graças ao estabelecimento da imagem fotográfica como traço; por outro, o cinema impôs de forma sistemática uma representação sobre a realidade. Esta dupla necessidade marcou de fato o século XX: necessidade de preservar o sentido do real ameaçado pelo avanço das novas formas de vida, os horrores da história, a perda da memória social, as dificuldades de reconstruir os níveis de existência. No entanto, mesmo preservando o sentido do real, Casetti constata a predileção ou inclinação tanto do cinema quanto do próprio século XX por participar sutilmente deste declive (CASETTI, 2008, pp. 191-192).

Chris Marker (1921-2012) poderia representar por si só esse caráter duplo conferido por Casetti ao legado do cinema e cujo sentido redefino da seguinte forma: evolução de uma arte-linguagem do real (impura), memória do século XX (atribulada). Não por acaso, Raymond Bellour define o autor de La jetée (1962)

Dossiê A Música e suas Determinações Materiais - https://revistaecopos.eco.ufri.br/ 
como o "homem-século" e o "homem-mundo" (BELLOUR, 2013, p. 2). Teria sido redundante defini-lo ainda como o "homem-cinema". São raros os cineastas modernos que, como Marker, têm desbravado e acompanhado passo a passo as novas tecnologias da imagem. E ele o fez com devoção até, mas sem fetichismo e, principalmente, a partir da plena compreensão do cinema (e de seu legado) em uma era caracterizada pelo simulacro e a hiperinflação visual e midiática. Vídeo, instalação, CD-ROM, internet ou multimídia eram para ele meios, não fins em si. Com tais meios, Marker continuava a dar forma, como antes fez em película de $16 \mathrm{~mm}$ e com o mesmo compromisso político, aos grandes e pequenos acontecimentos do século XX e da primeira década do XXI, nomeadamente os conflitos bélicos e os processos sociais e revolucionários.

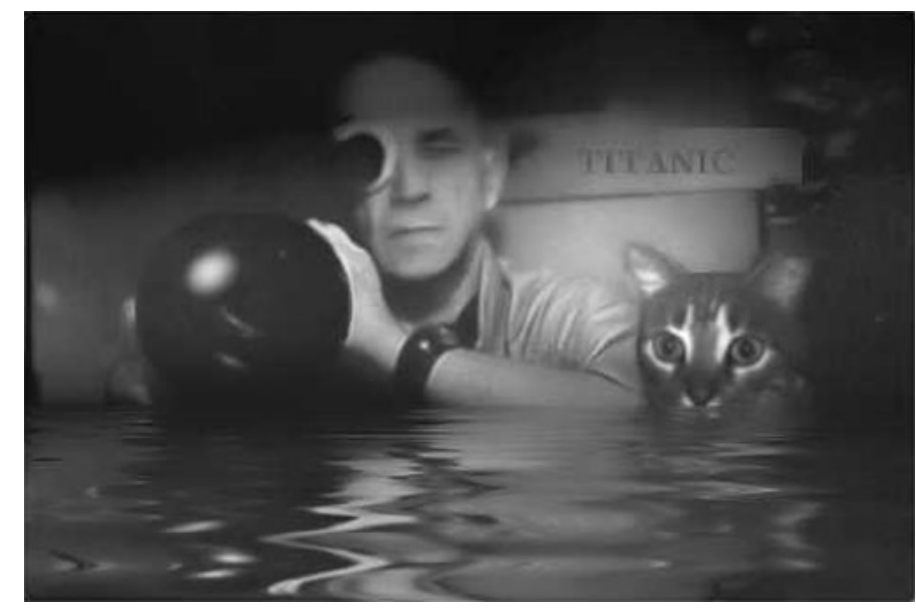

Chris Marker e Guillaume-en-Égypte

Com Chats perchés (2004), filme-palimpsesto de 58 minutos, Marker alcança a plena autonomia do documentarista transformado em homem-orquestra graças aos novos instrumentos: uma pequena câmera DV (Digital Vídeo, mas para o lúdico Marker poderia ser também Dziga Vertov), que "ele esperava fazia meio século" (GAUTHIER, 2011, p. 286), um computador e um software de edição. Em uma das raras entrevistas concedidas aos jornalistas, Marker responde assim à pergunta de se "as novas tecnologias modificaram de alguma forma sua relação habitual com as imagens e os sons":

Dossiê A Música e suas Determinações Materiais - https://revistaecopos.eco.ufrj.br/

ISSN 2175-8689 - v. 23, n. 1, 2020

DOI: 10.29146/eco-pos.v23i1.27549 
Necessariamente. Poder fazer todo um filme, Chats perchés, com meus dez dedos, sem nenhum apoio nem intervenção externa... E depois, ir eu mesmo vender o DVD que registrei nos saldos de Saint Blaise... Confesso que tenho um sentimento de triunfo: do produtor ao consumidor, tudo direto. Sem mais-valia. Cumpri o sonho de Marx (MARKER, 2008).

Não por acaso, a primeira acepção do vocábulo "digital", no Dicionário Priberam, diz "dos dedos ou a eles relativos": com eles empunhamos uma simples câmera DV ou apertamos um botão. Há também dedos anônimos que pintam gatos nos muros e tetos de Paris: o homem de 80 anos que sai sozinho em sua busca quase proustiana ("je parcours la ville a la recherche... de chats") tinha feito algo parecido, dessa vez junto com seus companheiros, com uma câmera de $16 \mathrm{~mm}$ no decênio 1967-1977 em Le fond de l'air est rouge (1978) ${ }^{1}$.

\section{Gatos sorridentes e protestos em Paris: "E tudo isso sob o olhar de um gato"}

O filme se articula em dois eixos guiados pela voz em primeira pessoa do autor, que tem sua fala transcrita em cartelas: os desenhos dos gatos amarelos de $\mathrm{M}$. Chat (forma abreviada de Monsieur Chat $^{2}$ ) e os numerosos protestos na cidade,

\footnotetext{
1 Guy Gauthier especifica as relações "biográficas" e artísticas de Marker com os gatos em sua resenha do filme, cujo título, "Le fond de l'air est chat" (O fundo do ar é gato), brinca com o do célebre documentário de Marker (GAUTHIER, 2004, pp, 68-70). O fundo do ar é vermelho "traça dez anos da militância pelo mundo todo, confrontando duas memórias: aquela das imagens, por vezes inéditas, filmadas pelos militantes [do grupo ISKRA] e a das imagens efêmeras da televisão. Construído em duas partes - as mãos frágeis e as mãos cortadas e levando o subtítulo de Cenas da Terceira Guerra Mundial 1967-1977, Le fond de l'air est rouge, cuja primeira versão dura quatro horas, alumbra este período da História contemporânea, e é uma das obras mais importantes de Chris Marker" (PARVOULI, 2013). Para um balanço dos críticos, em inglês e francês, que abordaram as conexões entre estes dois filmes de Marker, consultar Flinn (2009, p. 97). Os títulos dos filmes de 2004 e 1978, no mundo anglo-saxão, são respectivamente The Case of the Grinning Cat e A Grin Without a Cat, lançados juntos em DVD em 2008 como decorrência do sucesso do filme de 2004 nos festivais internacionais. Eles fazem clara referência ao sorriso do gato de Cheshire em Alice no país das maravilhas, de Lewis Carroll. Falando do grafismo e simbolismo das pichações de gatos assinadas por M. Chat, Marker aponta que "sua filiação com o grinning cat de Alice no país das maravillas era evidente mesmo que o francês aqui falhe: todas as traduções [de grining cat] propõem "o sorriso do gato", como se Carroll tivesse utilizado "smile", mas ele escreveu "grin", que não tem equivalente [em francês] e que seria sobretudo "o amplo, arreganhado sorriso". Ora, é evidente que este gato "grins". "Chris Marker e M. Chat: chats discutent", Entrevista a Chris Marker e Thoma Vuillon (autor dos desenhos M. Chat), Cf. Liberation, 4 de dezembro de 2004. Todas as traduções ao português feitas neste trabalho são do próprio autor.

2 M. Chat - escrito em letras maiúsculas quando, às vezes, aparece ao lado do desenho do gato - é criação gráfica e nome de guerra do artista franco-suíço Thoma Vuille. Ele apareceu pela primeira vez em 1997 e, a partir de
}

Dossiê A Música e suas Determinações Materiais - https://revistaecopos.eco.ufri.br/

ISSN 2175-8689 - v. 23, n. 1, 2020

DOI: 10.29146/eco-pos.v23i1.27549 
sendo que cada eixo, como veremos, se expande na arte e na política em função das profusas conexões e intervenções do cineasta. "E tudo isso - reproduzo aqui a cartela do autor após o flashmob, a primeira cena do filme - sob o olhar de um gato", na cidade de Paris de novembro de 2001 a outubro de 2003, com vários recuos ao passado recente e distante. "UM GATO?”, o autor pergunta a seguir com um gracejo, infletindo as maiúsculas a fim de expressar pasmo e deslumbramento. Cartelas, imagens e sons se embaralham numa montagem intensiva, ora digressiva, ora acumulativa, mas sempre sincopada, repleta de energia vital. A entidade social e política que é a cidade (pólis), e seu espaço mais caraterístico, a rua, a praça (ágora), erige-se em tema e chave do filme. 0 número e a efervescência das manifestações nas ruas, largos e praças são de tal ordem que parecem atenuar ou desmentir os pressupostos de que o espaço público mudara para o espaço televisivo (telepolis) ${ }^{3}$ ou para os shopping centers.
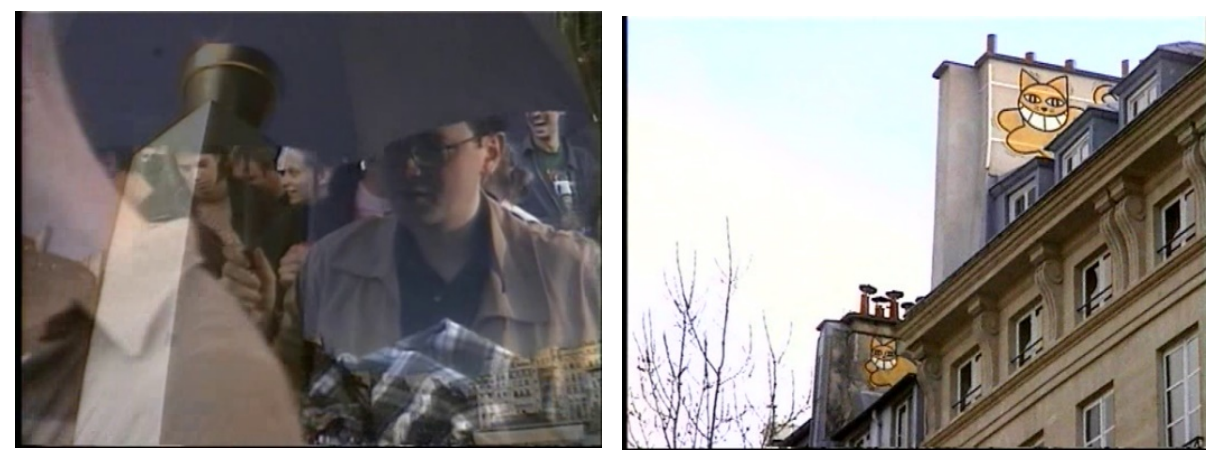

As perambulações pela cidade adotam o tom atmosférico de um street movie digital (herança das "sinfonias urbanas" a partir de W. Ruttmann) misturado com o diário de bordo e a crônica. Tudo é feito em um registro marcadamente subjetivo, sem dúvida o traço mais caraterístico do ensaio. 0 "eu" de Chats perchés - e do cinema ensaio de Marker - não poderia estar mais longe do relato confessional e autobiográfico; entretanto, tudo é embasado na sua experiencia vivida e pensada, na

2003, ganhou duas pequenas asas brancas nas costas. Para se aprofundar sobre seu trabalho de grafiteiro e acompanhar a proliferação deste emblemático desenho mundo afora, ver http://www.monsieurchat.fr/ 3 Ver Javier Echevarría, Telépolis, Barcelona: Destino, 1994. 
sua concretude e imediatez. Um "eu" que vai se construindo no devir, no seu precário e incerto caminhar (literal e metaforicamente, pois o sujeito é transeunte como o seu objeto: os desenhos e os humanos na - e da - rua). "A escrita do ensaio é radicalmente crítica e antiautoritária, errante e testemunhal, hostil a qualquer método lógico-discursivo" (CUNHA, 2011, 574). Esse "eu”, essa voz, é a única consciência que se singulariza em face do sujeito coletivo (polifônico) que se manifesta nas ruas ou das vozes que falam na mídia (notadamente, de políticos e âncoras de telejornal), vozes que são reformuladas a partir de "estratégias de agressão" (N. Burch). Não há, no filme, nenhuma entrevista in situ de um indivíduo com o documentarista. Por isso, a única conversa, no sentido forte do termo, é a do autor com o espectador, justamente a figura que, na recepção, é interpelada e apreende as imagens e sons como pensamento(s) em ato.

O filme de Marker se apoia, fundamentalmente, no imaginário cultural ligado à figura felina e na "interpretação poética do real" (MASSART, 2013). 0 exemplo mais claro é o grafite, "uma arte que, fugindo dos templos, propõe aos passantes um lampejo de beleza, um sorriso" (GAUTHIER, 2011, p. 286), apesar da perigosa intervenção que acarreta pintar os gatos pendurados - tal é o significado de perchés - nos tetos e chaminés dos prédios ("Assim alguém, de noite, corria o risco de quebrar o pescoço para fazer flutuar um sorriso sobre a cidade"). Outro exemplo: a pomba que desaparece pelos corredores do metrô e "se transforma em homem". 0 metrô, por falar nisso, antes de ser o cenário de alguns "sinais" markerianos, é parte da vida urbana com suas ruelas subterrâneas onde os caminhantes podem espontaneamente se encontrar para desfrutar da música ao vivo, por vezes tocada por músicos vindos de outros países. A partir dos desenhos de M. Chat espalhados pela cidade, Marker configura uma "genealogia" bem-humorada deste felino na arte e na cultura popular. A paixão do cineasta pelo Japão é percebida na hora de ele escolher figuras deste país (Miyazaki, mangás, publicidade) em lugar de, por exemplo, as marcantes personagens dos cartuns norte-americanos (Felix the Cat, Mickey Mouse, Tom \& Jerry, Fritz the Cat, Garfield, etc.). Marker situa o sorriso de M. Chat na esteira do gato de Cheshire, mas é sobretudo ele próprio que se imbui do 
espírito da figura carrolliana (pois do espírito dos grafiteiros, ele o tem em demasia). Agora M. Chat se espalha virtualmente por toda a história da pintura, desde a caverna de Chauvet até o construtivismo russo, como depois o fará nos selos das cartas "enviadas" a cineastas vivos e mortos (homenagem) ou viralizando até nos sites norte-americanos mais poderosos (gozação). Os gatos podem estar no Museu do Louvre (belas esculturas da arte egípcia que, Marker aponta com sarcasmo, ele "levaria" como outros "pilham" nos museus de Bagdá) ou nos grafites, cartazes e grafismos do "museu das ruas", incluindo as telas eletrônicas das estações onde desfilam deliciosos loopings de M. Chat. Depois disso, há apenas um passo para as intervenções ex professo de Marker nas imagens das grandes mídias, como analisarei no ponto seguinte. Finalmente, como não poderia deixar de ser, o cineasta também inclui os animais "reais". Enquanto as pessoas que percorrem as ruas são anônimas, os gatos Boléro e Caroline se individualizam com suas pequenas anedotas. Sirva como exemplo a forma como Marker apresenta o gato Boléro e sua dona, uma semteto que pede esmola no metrô: "Boléro, o gato de Strasbourg Saint-Denis, e sua humana".
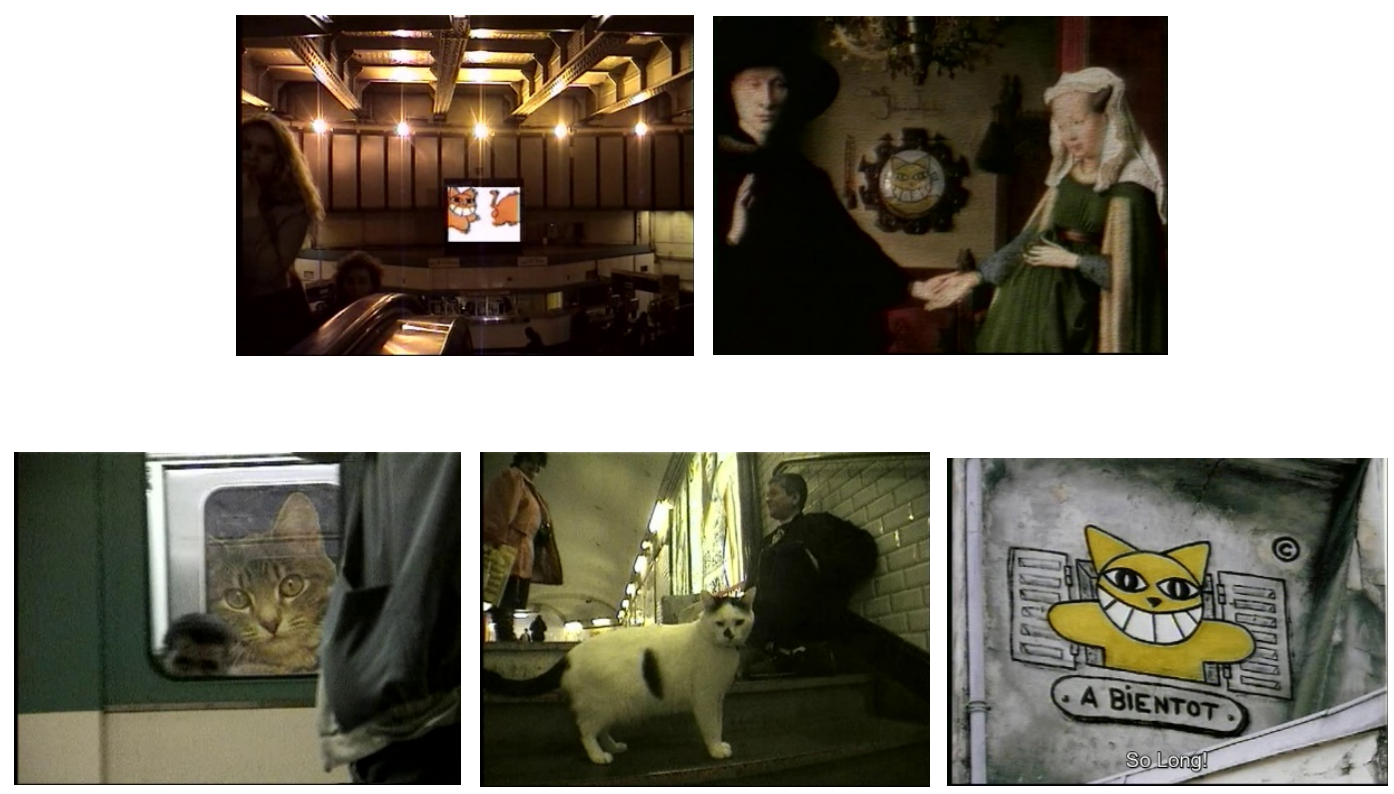

Dossiê A Música e suas Determinações Materiais - https://revistaecopos.eco.ufrj.br/

ISSN 2175-8689 - v. 23, n. 1, 2020

DOI: 10.29146/eco-pos.v23i1.27549 
A esfera dos gatos funciona no filme como fio condutor que dá forma ou figura a uma série de acontecimentos, grandes e pequenos, domésticos e internacionais, que ocorrem no conturbado período pós-setembro de 2001 ("0 eco das cornamusas de setembro estava ainda no ar"). 0 título do filme também faz referência, num jogo de palavras típico de Marker, ao jogo infantil de perseguição chamado "chat perché" (que tem tantas variantes quanto denominações: pega-pega, gato e rato, polícia e ladrão, etc.), e o autor, amiúde, refere-se a esta figura com maiúscula inicial (Chat). 0 caraterístico estilo leve, próximo, bem-humorado de Marker se vê energizado pela esfera dos Chats a ponto de o filme todo parecer uma história em quadrinhos. De fato, além do humor e do tom brincalhão do filme incluindo a trilha sonora -, é marcante a presença dos recursos da animação e do mundo gráfico: intertítulos, desenhos de animais, balões, caricaturas, cartazes, grafismo digital e especialmente o assim denominado The Morpheye, que explicarei mais adiante.

Em contraposição à esfera política dos acontecimentos históricos, a constelação (figural) dos gatos implica um universo poético que revela a "intenção artística" (AUERBACH, 1996, p. 52) do autor desse dispositivo que emoldura aquela sob o olhar desta. Certamente, a esfera da pichação dos gatos não é mero pretexto ou abstração, ela está na mesma ordem de ação da esfera pública da cidade - no caso, algo que pode aparecer, desaparecer ou reaparecer nos muros ou nas ruas. Porém, à medida que o filme avança, a anedota presencial (física) dos felinos decresce em benefício do seu sentido metafórico e/ou "figural". 0 gato é uma figura que nunca se completa nos jogos lúdicos e imaginativos do autor, aberta tanto a "escavações" da memória - no sentido benjaminiano4 - quanto a prefigurações ou

\footnotetext{
${ }^{4}$ Imagens que pensam (Denkbilder) é o expressivo título do Livro IV das Obras completas de Walter Benjamin onde é incluído o texto que cito aqui, "Escavar e lembrar": "Aquele que quiser aproximar-se a seu passado sepultado tem de se comportar como um homem que escava. [...] Os 'conteúdos' não são outra coisa que essas camadas que só depois de uma investigação cuidadosa entregam tudo aquilo que vale a pena escavar: imagens que, separadas de seu contexto anterior, são joias nos sóbrios aposentos de nosso conhecimento posterior, como quebrados torsos na galeria do colecionador. [...] Por isso, as lembranças mais verazes não têm por que ser informativas, elas apenas devem indicar o lugar onde foram adquiridas pelo investigador" (p. 350). Além dos flashbacks sinalizados com cartela, Marker sempre marca o 'lugar' de seu "itinerário com as interrupções da memória" ou alusões ao "tempo remontado". Três exemplos: a citação ao Hôtel du Nord, de M. Carné (ver supra); perante o clima de greve geral em maio de 2003 o cineasta "desativa" o discurso ufanista em prol dos valores republicanos feito pelo primeiro-ministro Raffarin um ano antes "na embriaguez da vitória", típica situação de
}

Dossiê A Música e suas Determinações Materiais - https://revistaecopos.eco.ufrj.br/ 
presságios, fragmentos aparentemente desligados que reverberam como "figuras ou sombras do futuro" (typos méllontos, umbra futuri) ${ }^{5}$. Não por acaso, a esfera dos M. Chats adota frequentemente, na fala do narrador, uma interrogação que, mesmo escorada na retórica, tensiona momentos de ruptura e suspensão do discurso: “UM GATO?", "eles têm ambições políticas?", "onde eles estão?", "o que o Gato vai se tornar?", "E se eles nos deixassem definitivamente?". As manifestações têm presença constante na mídia e nas redes sociais e, via de regra, são sempre marcadas pelos organizadores, como ocorre na cena já referida do flashmob na praça do Centre Pompidou, pontuado pelo sentido lúdico na hora de sincronizar os movimentos dos corpos e dos guarda-chuvas a cada dez segundos a partir da hora marcada. A esfera única e singular dos gatos, como igualmente ocorre nas cenas no metrô, terreno de uma maior intervenção inventiva do autor, ultrapassa tanto o tempo cronológico ${ }^{6}$ e histórico quanto a visão limitada a ideologias e partidarismos políticos7 .

desmascaramento de um político que Marker compara, a meu ver de maneira forçada, com os slogans no final dos anos sessenta contra o presidente Johnson, a guerra de Vietnã e o apelo para "continuarmos na luta"; finalmente, os grevistas do mundo do espetáculo parodiam Raffarin cantando com fingido patriotismo uma canção dos anos 1940, e o cineasta faz uma pausa no momento em que a letra menciona o termo Kommandantur (quartel-general), uma 'imagem que pensa'.

${ }^{5}$ A esfera dos gatos está mais próxima da metáfora e do símbolo do que da alegoria. Como veremos na conclusão, na trama narrativa que o filme elabora a partir do acontecer "figural" dos gatos não se objetiva uma réplica da concepção teleológica da temporalidade de Auerbach (grosso modo, entre dois fatos históricos desligados, sem causalidade, há uma sorte de "fragmentarismo totalizador": um fato prefigura outro e este o completa), mas a intensificação do olhar crítico e estético sobre o tempo histórico atual. Para isso, a "interpretação" da figura é tão importante quanto a "interpretação" da sua desaparição.

60 site denominado "relógio falante" (https://www.horloge-parlante.com/) foi utilizado pelos organizadores do segundo flashmob da cidade, o ParisMob, com o intuito de ter uma sincronização precisa nos gestos de abrir e fechar os guarda-chuvas dos participantes enquanto se movimentam, no sentido horário, ao redor do monumento da praça Beaubourg, um pote - pot em francês - dourado colocado sobre um pedestal, razão pela qual este evento lúdico é chamado Pot-pidou. Retomando o ar surrealista de atos poéticos de outros tempos, o flashmob pede aos participantes "cantar de maneira monocórdia o seguinte: "rodopiemos por volta do pote até que a chuva faça nascer a flor dourada". Afinal, o que este exercício brincalhão de magia coletiva atingirá no filme é a aparição do primeiro desenho de M Chat.

7 Chats perchés começa retomando o fio de certas constantes formais e temáticas da obra de Marker a partir de 1978 (Sans Soleil - 1982 -, 2084 - 1984 -, Level Five - 1997 - e, notadamente, suas instalações): as novas imagens tecnológicas e a memória individual, a atualização digital da forma epistolar, a voz sintetizada, a forma televisual e/ou computadorizada, o motivo identificador da coruja, etc. Nessa primeira sequência do filme destacam-se duas pautas de Chats perchés: o close de uma mulher negra no metrô (a primeira imagem propriamente "documental" do filme) e o corpo inerte no chão do clochard nos arredores do Centre Pompidou (do sujeito que está fora da "sincronia do tempo" social). Uma certa atenção pelas mulheres e pelos indigentes também é observada em um filme precursor das sinfonias urbanas, também rodado em Paris: Rien que les heures (1926) de Alberto Cavalcanti.

Dossiê A Música e suas Determinações Materiais - https://revistaecopos.eco.ufri.br/ 

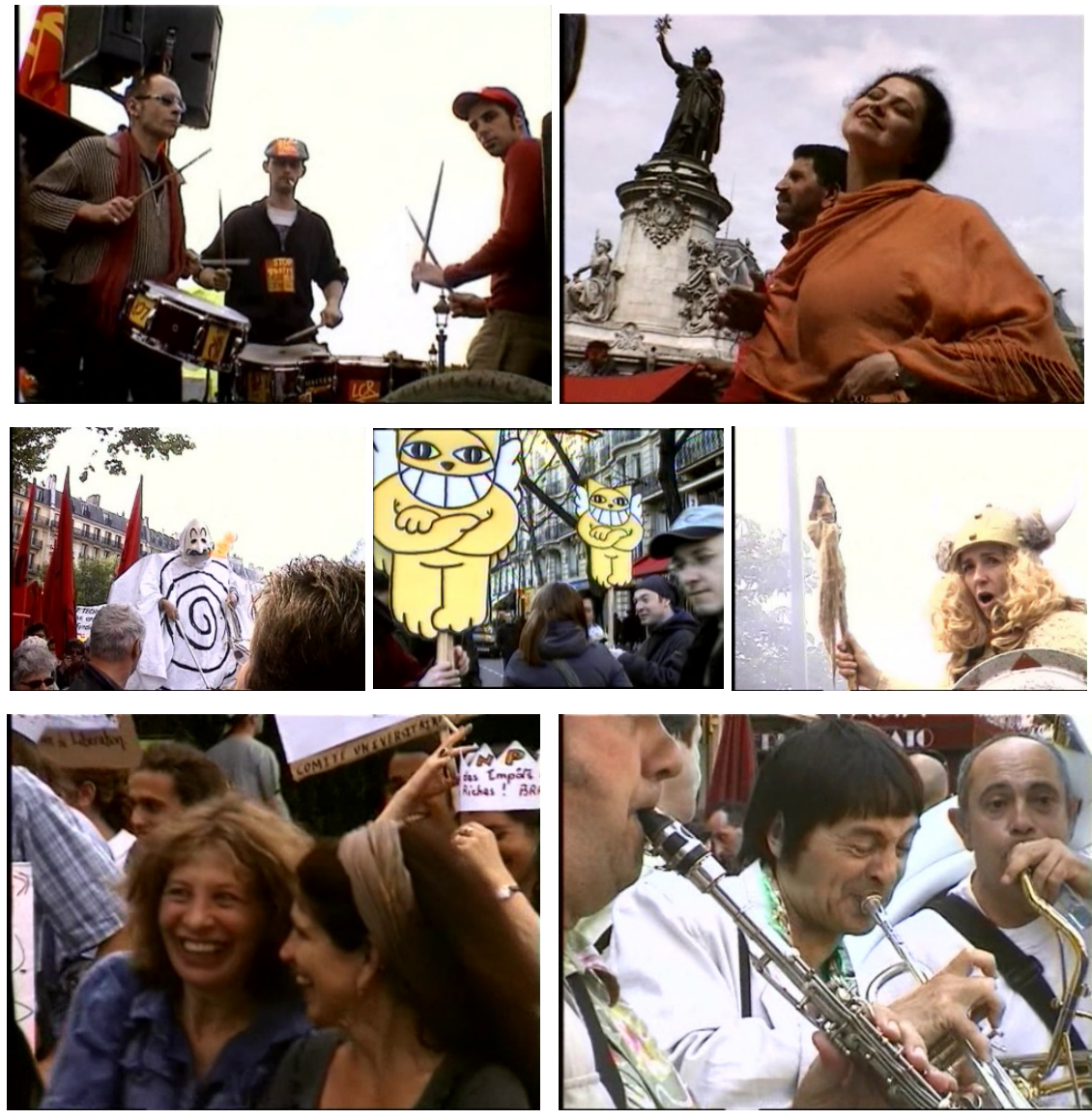

Marker filma e monta os protestos das pessoas nas ruas como rituais em que slogans, palavras de ordem ou reivindicações são encenados por meio de cantos, fanfarras, danças, fantasias, máscaras, cartazes, momentos de amor e partilha de experiências. Há muito do olhar desse gato insubmisso de sorriso arreganhado nesse caráter dionisíaco com que Marker pontua (porquanto captura e escolhe tais imagens-sons) o "bulício festivo" das manifestações na cidade: personificação das celebrações do entusiasmo coletivo, festivo e embriagante, Dioniso não apenas se apresenta como um estrangeiro que gosta de se fantasiar, mas como marginal e estranho, transgressor das normas cívicas (dos limites e da ordem da cidade), figura essencial da alteridade (GARCÍA GUAL, 2003, pp. 105-112).

\footnotetext{
${ }^{8}$ M. Detienne (apud GARCIA GUAL, p. 110) destaca que "uma das maiores virtudes do dionisismo é a de misturar as figuras da ordem social e questionar os valores políticos e masculinos da cidade [...], acolhendo não apenas aqueles que são excluídos dos cultos políticos, como os escravos e as mulheres, mas também impondo na cidade, e fazendo emergir entre os olímpicos - ele próprio fazendo parte deles - a figura da Alteridade". A citação parece sintetizar não apenas Chats perchés, mas o próprio espírito inconformista de Marker, que por sinal realizou
}

Dossiê A Música e suas Determinações Materiais - https://revistaecopos.eco.ufrj.br/

ISSN 2175-8689 - v. 23, n. 1, 2020

DOI: 10.29146/eco-pos.v23i1.27549 
Esse élan dionisíaco parece guiar as atividades político-artísticas da cidade (política na arte das ruas, artes populares na política dos cidadãos que se reúnem e manifestam), produzidas anonimamente como uma vibrante celebração coletiva e, assim sendo, elas não aparecem separadas, legitimadas ou fetichizadas pelas instituições modernas das artes:

Só nos tempos modernos fomos separando cada uma das atividades artísticas e fomos nos acostumando a avaliá-las em separado, como se fossem autônomas e se justificassem por si mesmas fora do espaço e do tempo, fora da cidade, flutuando na abstração. Mas as artes desligadas [desprendidas] de seu suporte cidadão viraram rapidamente filosofia da arte, e por causa disso as imaginamos isoladas e reflexivas, como ilustrando as páginas de um livro ou a tela de um televisor (grifo do autor, AZÚA, 1995, p. 88).

\section{Espaço de intervenção: reformulação da mídia, jogo e plasticidade}

Marker, munido de sua câmera-caneta ${ }^{9}$ digital, assume uma atenção mais tátil aos elementos compositivos da imagem-som. É evidente que a camcorder dúctil, autônoma, protésica - lhe fez empregar a câmera na mão e o zoom com mais frequência do que no passado. Entretanto, mesmo colada ou fincada ao corpo, a câmera exploratória de Marker nunca perde a primazia do olhar (e da mise-enscène), diferentemente do que ocorre nas narrativas audiovisuais na chamada era digital que aguçam o fluxo, a sensorialidade, o corpo-a-corpo. As enfáticas aproximações aos desenhos de M. Chat nos tetos da cidade podem apresentar o olhar inquieto e curioso de uma descoberta (sublinhada, por vezes, com a música e/ou em slow motion ${ }^{10}$ ), ou o desejo de incorporar, por meio de um grande plano

L'Héritage de la chouette (O legado da coruja), a extraordinária série de TV de 13 capítulos sobre a cultura da Grécia antiga que "deveria figurar no programa de todas as escolas" (BELLOUR, 2013, p. 3).

${ }^{9}$ Aqui a referência ineludível é a caméra-stylo de A. Astruc (1948): "Uma linguagem, ou seja, uma forma na qual e pela qual um artista pode exprimir seu pensamento, por mais que este seja abstrato, ou traduzir suas obsessões do mesmo modo como hoje se faz com o ensaio ou o romance. É por isso que eu chamo esta nova era do cinema de caméra stylo".

10 Para enfatizar o primeiro M. Chat do filme, Marker sinaliza na praça do Centre Pompidou o afastamento da arte institucional com "seu discutível troféu" (o pote dourado sobre a coluna) e o ingresso para a arte rebelde dos grafites por meio de um movimento do corpo e um lento zoom in, acompanhado de música eletrônica. No entanto, também se percebe, no filme, certa deferência ou familiaridade do autor com este centro, pioneiro na concepção museográfica e expositiva do cinema contemporâneo. Marker trabalhou com o Pompidou desde 1978

Dossiê A Música e suas Determinações Materiais - https://revistaecopos.eco.ufrj.br/

ISSN 2175-8689 - v. 23, n. 1, 2020

DOI: 10.29146/eco-pos.v23i1.27549 
geral, a comunhão da cidade com os sorridentes felinos amarelos (para este fim se usa tanto o zoom de aproximação quanto o de afastamento). Em outro momento, o zoom out revela aos poucos a enorme fenda de uma árvore, que tem o rosto do gato desenhado nas texturas estriadas do vegetal (a referência aqui é a milenar sequoia de Um corpo que cai, A. Hitchcock, 1958). Os grafismos dos gatos parecem vivificarse - como em um desenho animado - quando vislumbrados através das janelas de um trem em movimento, ou dão as boas-vindas aos viajantes nas estações (no caso, a uma mulher muçulmana).
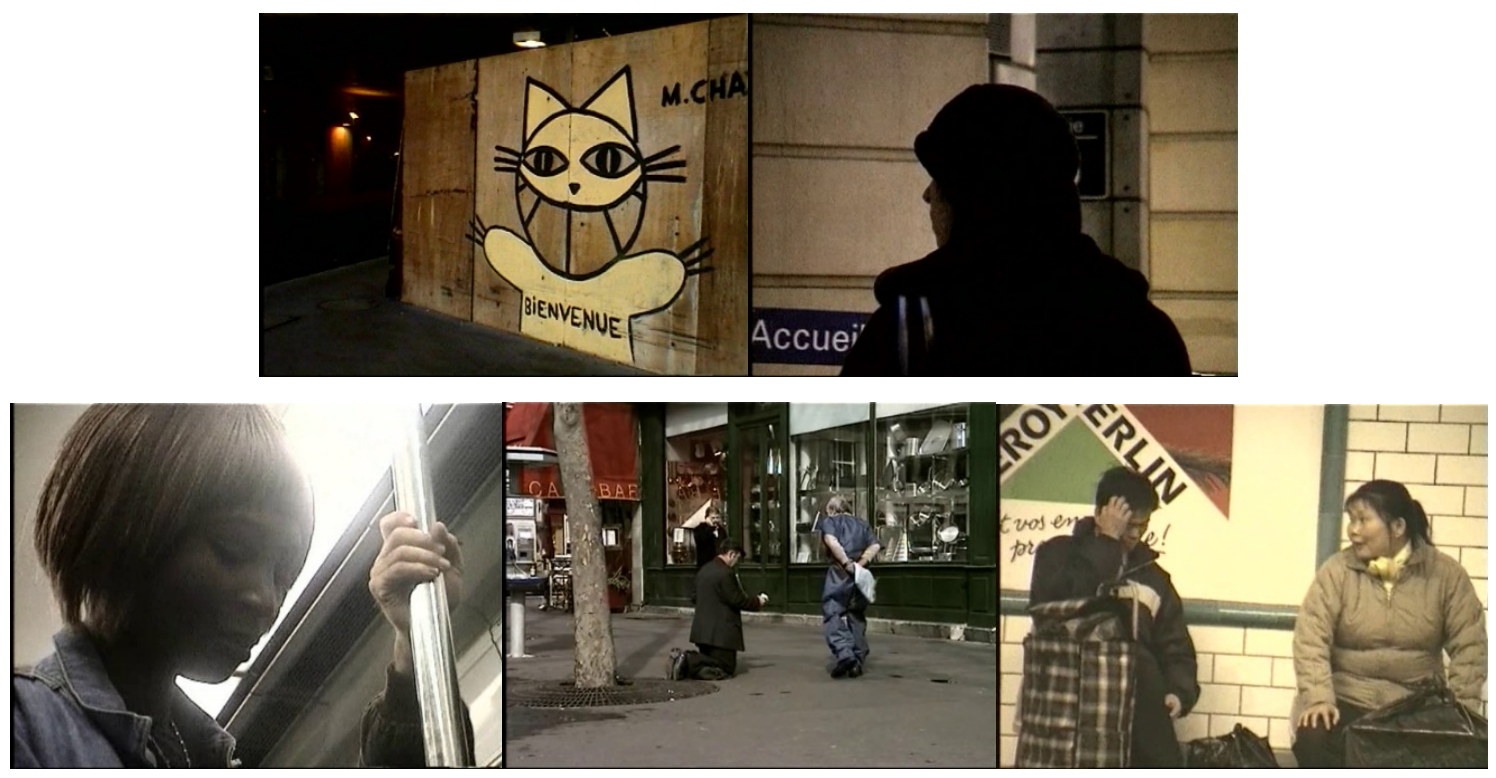

Além dos felinos, o filme todo mostra uma atenção especial aos (rostos de) imigrantes, mulheres ${ }^{11}$ e excluídos. E o faz com esse estilo singular de Marker, tocando "de leve com imagens fugidias e calorosas" (GAUTHIER, 2011, p. 286), tom que ele mantém mesmo detendo, retardando ou alterando a imagem em preto e branco (podendo ou não acompanhar estes recursos com breves citações musicais). Em outros momentos, a câmera na mão - o recurso principal do filme - faz um

e mais intensamente com suas obras multimídia desde 1986: Quand le siècle a pris formes (Guerre et Révolution), 1978; Zapping Zone (Proposals for a Imaginary Television), 1990; Immemory, 1997; Ouvroir. The Movie, 2009 e o site Gorgomancy, 2007-2013.

11 Marker fez Metrotopia (2008, 4', preto e branco), um pequeno filme de montagem, a partir de "Passengers", sua série de fotos de mulheres feitas no metrô de Paris (PARVOULI, 2013, p. 65).

Dossiê A Música e suas Determinações Materiais - https://revistaecopos.eco.ufri.br/

ISSN 2175-8689 - v. 23, n. 1, 2020

DOI: 10.29146/eco-pos.v23i1.27549 
movimento rápido entre dois objetos arremedando o mesmo efeito de um choque de planos na montagem. Assim ocorre quando articula um sintagma com a memória do cinema (do rótulo Hotel du Nord de um prédio ao desenho de M. Chat na ponte do canal de Saint-Martin, momento antecedido pelo barco chamado Marcel Carné e pelo breve trecho sonoro do filme citado $^{12}$ ) ou quando vai de um avião com seu rastro branco ao desenho do felino no alto de um edifício, que desta vez dá um pulo de alegria (plano que aprimora aquele que vai do "gato no telhado" até o rótulo "Hotel Utopia" de Sans soleil).

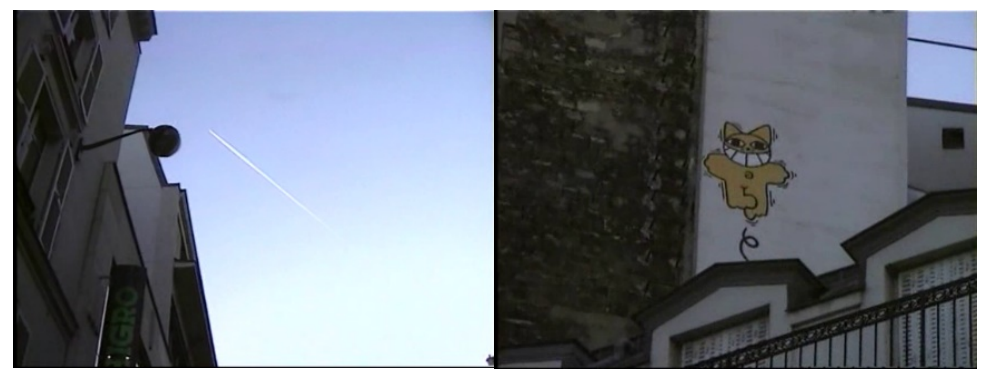

Este grafite do gato pulando aparece no início do filme, logo depois de mostrar a fusão do skyline de Paris com o recorte, por meio de um simples efeito digital, das Twin Towers de Nova York sendo consumidas pelo fogo. As duas imagens - as duas cidades - "confraternizam" por uns instantes, como se as Torres Gêmeas fizessem parte de Paris ${ }^{13}$. Marker, criterioso, se recusa a usar o hipermidiatizado momento dos impactos dos aviões. No entanto, o avião que atravessa o céu de Paris e "provoca" o pulo do Chat está a vindicar o lado singelo e afável da vida (que continua). Os grafites de gatos sorridentes - emblemas de liberdade, resistência e utopia - que Marker vê proliferar em "Paris" a partir de "novembro de 2001" cartela que vem logo após a fusão - parecem pedir um momento de calma e reflexão

\footnotetext{
12 Marker, sempre sagaz, extrai de Hotel du Nord (1938) um engraçado diálogo entre Louis Jouvet e Arletty que enfatiza o termo "atmosfera".

13 É a imagem/plano de Paris que "acolhe", pouco depois de ter começado, e antes de terminar, a imagem/efeito de Nova York. A torre Saint-Jacques, à esquerda, coberta pelos andaimes, e a torre Montparnasse, ao fundo, dialogam, a partir de uma falsa escala, com as Torres Gêmeas. Marker escolheu o piso superior do Centre Pompidou para filmar tal vista da cidade. A modesta camcorder torna ainda mais despretensioso este skyline de Paris nada convencional.
} 
perante a forte ressonância, "ainda no ar", dos atentados de 11 de setembro. De fato, toda a sequência é pontuada pela gaita de fole e a percussão de “Amazing Grace” em homenagem às vítimas.
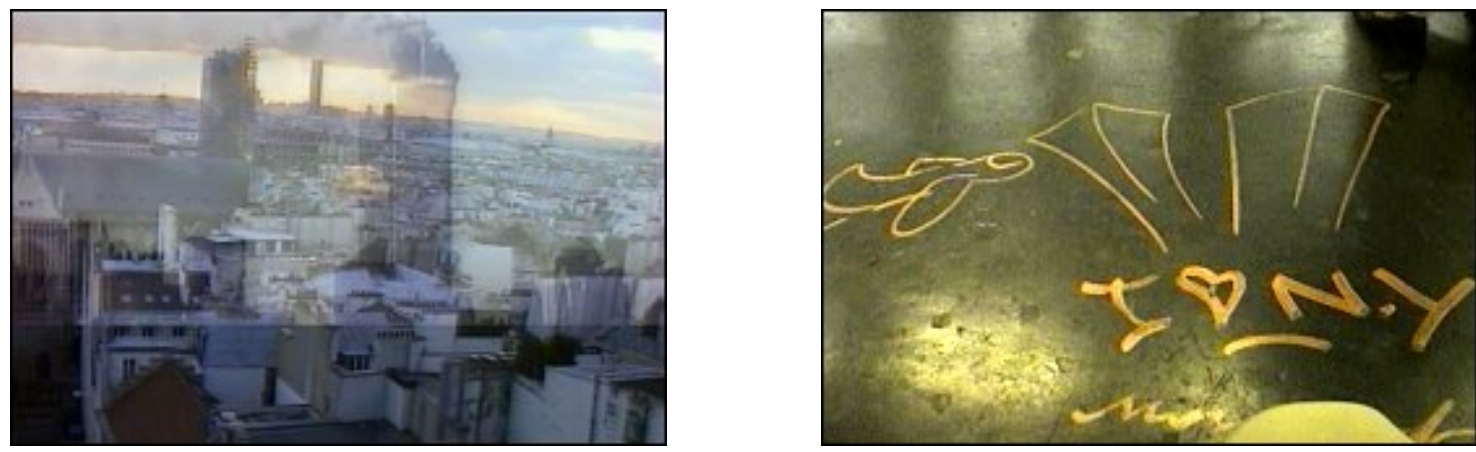

Um desenho anônimo no chão do metrô será identificado com Tony Blair como a cogitar, de ricochete, sobre a responsabilidade dos governantes no novo terrorismo transnacional - na sequência em que Marker arranja esse espaço como palco da guerra do Iraque. No dia "19 de março [de 2003] Bush anuncia o início da guerra", nos diz uma cartela enquanto ouvimos uma dramática contagem regressiva: four, three, two, one. (Ela, por certo, rima com a contagem "progressiva" dos manifestantes que abrem este segmento: "One, two, three, four. We don't want your fucking war!"). "To defend the world from grave danger" proclama George W. Bush no depoimento, transformado em fantoche pelo The Morpheye ${ }^{14}$. Marker filma então as pessoas que descem as escadas do metrô como se estivessem entrando em um abrigo subterrâneo. Duas cartelas em francês traduzem a voz off de Tony Blair: "O Iraque possui armas químicas e biológicas que poderiam ser ativadas em menos de 45 minutos". A seguir, pulsando na montagem a iminência do bombardeio, o referido desenho das torres e o avião acima da inscrição "I love $N Y$ ” recebe reflexos e sombras. A figura do "coração" (significando "love") é semelhante a um "O" compondo o nome, a modo de assinatura, de TONY. A câmera sobe e descobre que

\footnotetext{
${ }^{14}$ Assim chamado por Marker, The Morpheye é um recurso digital no qual as imagens e sons, tiradas dos telejornais, são manipuladas - cores em tom pastel, desaceleração, voz distorcida - a ponto de simular o desenho animado e criar distanciamento. The Morph-eye, junção de morph ou morphing (efeito digital) e eye, poderia ser traduzido como $\mathrm{O}$ olho metamorfoseado/r.
} 
tais sombras são produzidas pela chegada do trem ${ }^{15}$. Uma cartela responde ao midiático estadista britânico: "Os inspetores da ONU não encontram rastro dessas armas". Não é descabido perceber, nesse trabalho de desmontagem do relato oficial da mídia e da geopolítica hegemônicas, a flexão de uma questão maior em que aquele se subsome, isto é, a tentativa de reabilitar a categoria da verdade que fora uma e outra vez comprometida pelas deposições e autocomplacências da pósmodernidade ou, se se preferir, da modernidade (in)cessante ${ }^{16}$.

Fora as imagens e sons da mídia retrabalhados pelo Morpheye, há poucas imagens de arquivo no filme. 0 aqui e agora é a cidade de Paris, e Marker se recusa a mostrar imagens da guerra - ela própria também midiática, com a data "marcada": "20 de março bombardeio de Bagdá". A arte que a represente deve ser cosa mentale: sons de bombas e projéteis acompanham as imagens dos passageiros pelas esteiras rolantes do metrô. Algumas imagens terminam com rápidos chicotes da câmera. Outras, acaso manipuladas digitalmente, fazem contrastar tons de sépia contra preto. 0 dramatismo da sequência do "bombardeio no abrigo-metrô" se acentua com os sucessivos escurecimentos que a pautam e a música atonal de cordas com que finaliza. Após uma nova vinheta em Morpheye com a gritante exibição do recado de Bush - "Mission accomplished" - num porta-aviões e um novo lembrete de Marker sobre o "pas de traces" a respeito das armas de destruição em massa (ADM), um jornalista da Skynews "coloca a questão certa": "Será que esta guerra entrará na História por ter terminado antes de ter encontrado sua causa?”. Um balão com a típica onomatopeia de "engolir saliva" arremata a falta de resposta do alto oficial militar dos Estados Unidos enquadrado pelo Morpheye.

\footnotetext{
15 Não é preciso retomar aqui os usos e significados da sombra ao longo da história do cinema e que teve seu apogeu no expressionismo alemão. Essas sombras que pairam sobre o desenho do ataque às torres (fantasmas ou espectros que provocam medo, pânico, inseguranças, crises, guerras...) procedem apenas do trem que chega, tal como revela um simples movimento de câmera (por sinal, da perspectiva de um simples passageiro sentado na estação). Não se trata de negar os perigos e ameaças reais, "do terror e do terrorismo (de Estado ou de partido, de igreja, de seita ou de mercado)", mas da gestão política que é feita ou imposta a partir dessas sombras ou espectros. "Operador político de primeira magnitude, o medo passou de ser um estado de exceção, ou quiçá anomalia, a ser um paradigma, uma exceção permanente" (LANCEROS, 2017, pp. 79-81).

${ }^{16}$ A fragilidade da(s) verdade(s) e do(s) sujeito(s) nunca foi tão patente. Como a escultura de gelo com a palavra TRUTH de M. Reese e N. Ligorano apresentada em um protesto poético em frente do Capitólio, em Washington, em 22/09/2018. Além do problema da verdade, o filme todo tenta recompor outros conceitos desacreditados pela globalização, como justiça, liberdade, igualdade ou dignidade.
} 

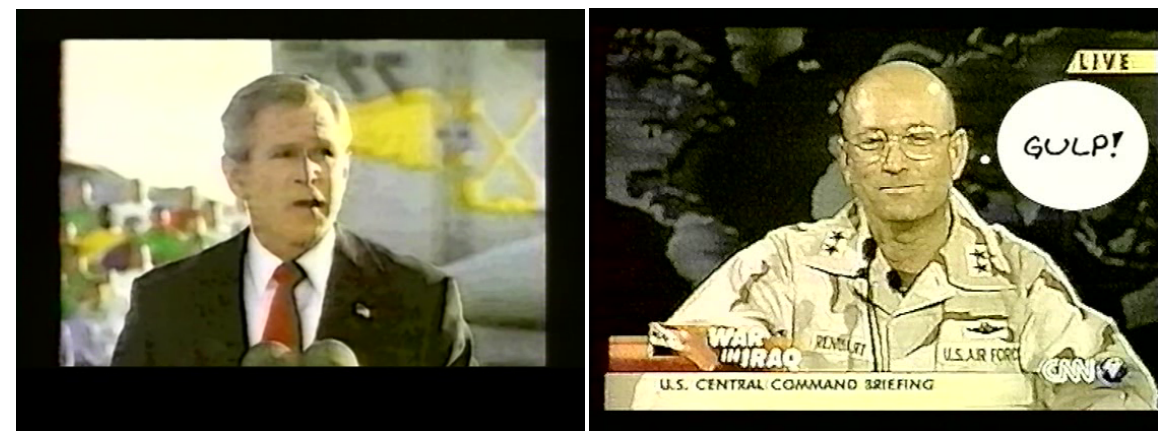

No relato da agitada campanha presidencial francesa de $2002^{17}$, Marker evita fazer qualquer comentário, recorrendo àquilo que é a marca mais direta de sua subjetividade: as cartelas em quadro negro. Apenas se permite que elas veiculem, em quatro momentos consecutivos que encerram o bloco do primeiro turno, os depoimentos entre aspas de quatro líderes da esquerda. Parece-me que há aí certa compreensão - fatal ou cética, tanto faz - da divisão da esquerda e aquiescência com quem declara a "deriva à direita” de L. Jospin (R. Hue, o líder do PCF), sua ligação com a "grande patronal" (crítica de dois líderes da extrema-esquerda, 0. Besancenot e A. Laguillier) e, finalmente, um comentário de efeito bumerangue do líder dos verdes e aliado de Jospin, N. Mamère, que declarava com ufanismo que "não ver Jospin no segundo turno, era tomar os franceses como imbecis".

\footnotetext{
$17 \mathrm{Na}$ minha análise, inverti a cronologia e comecei pelo relato da guerra do Iraque (2003) antes das eleições (2002), uma vez que a questão da eclosão dos M. Chats em Paris no contexto pós 11 de setembro é crucial no filme. Por outro lado, estes dois eventos, os mais importantes do filme, são contraponteados por Marker. Enquanto o início da guerra de Iraque é "performado" pelas pessoas que descem fisicamente pelas escadas do metrô-abrigo (o acesso é literalmente um buraco na terra), o início da campanha eleitoral de 2002 é "performado" pelas pessoas que saem "inertes" do metrô, autômatos trazidos à superfície pela escada rolante (aqui a automatização pode ver-se como uma icástica metáfora da condição do cidadão perante a progressiva deslegitimação das instituições políticas e as visões puramente instrumentais da democracia, cada vez mais esvaziada de conteúdo).
} 

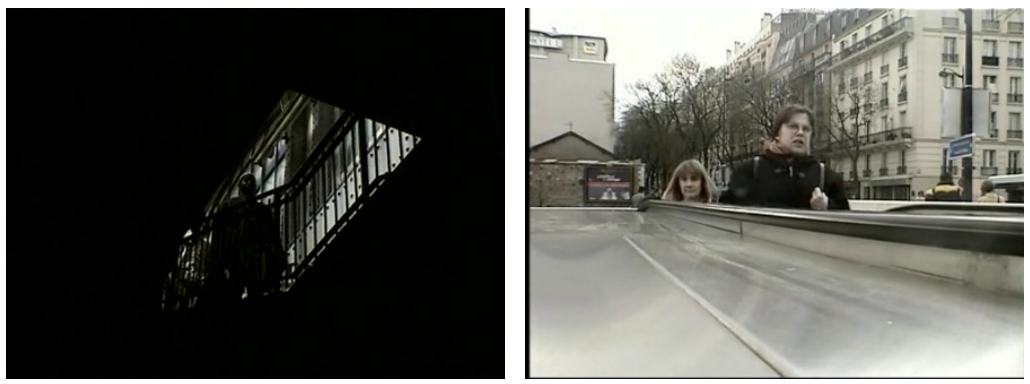

Não há, portanto, comentário direto na fala de Marker sobre a campanha, exceto um comentário inabalável acerca de Le Pen ${ }^{18}$. Porém, o tom bem-humorado, levemente irônico do filme se acentua com o emprego de certos recursos

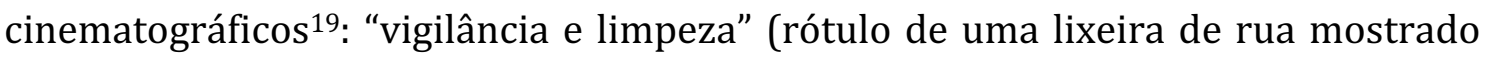
em zoom out) e "2002" (ano eleitoral) são citados a colidir como signos visuais em dois planos consecutivos (as imagens de "Novo Ano" e "2002" em luzes brancas projetadas no chão de um shopping é motivo de brincadeira para as crianças que tentam pegá-las); dissimetrias e rupturas entre som e imagem; vozes off de candidatos extraídas da mídia (discursos de Chirac, Jospin e Le Pen) enquanto na banda imagem são mostrados os mendigos das ruas (no caso de Le Pen, ainda em slow motion); gags visuais; riffs de guitarra na banda som pontuando o sarcasmo; montagem vertiginosa de imagens da mídia e, notadamente, o recurso digital já referido, The Morpheye, cujo efeito criticamente distanciador operado sobre algumas figuras/discursos - aqui os políticos e comentaristas franceses e, em outros momentos, Bush e aliados - é demolidor.

\footnotetext{
18 Enquanto na banda som há o registro off de vozes de políticos da Frente Nacional ou de jornalistas falando do líder desse partido de extrema-direita, Marker mostra as imagens das manifestações do primeiro de maio, marcadas pelos gritos contra Le Pen. Marker compara os tempos atuais com os agitados anos 30-40 do século passado: "Não há mais legiões de fascistas às nossas portas e Le Pen é um ditador apenas para seus adeptos, mas é toda uma geração que se reputava apolítica entrando em cena". Mais adiante, ele compara a efervescência das manifestações na greve de 2003 com a Frente Popular de 1936.

${ }^{19}$ Não é aqui o lugar para analisar as plausíveis influências do cine-olho de Vertov, que Marker reconhece como mestre e mentor. Seria necessário outro trabalho para estudar as correspondências técnicas, estéticas, políticas (freeze frame, sobreimpressão, slow motion, aceleração, fragmentação, animação etc.) que ambos os cineastas empregaram na exploração cinemática da vida urbana. Porém, o legado do cinema dialético de Eisenstein, especialmente da montagem vertical imagem-som, me parece mais evidente em Chats perchés.
} 

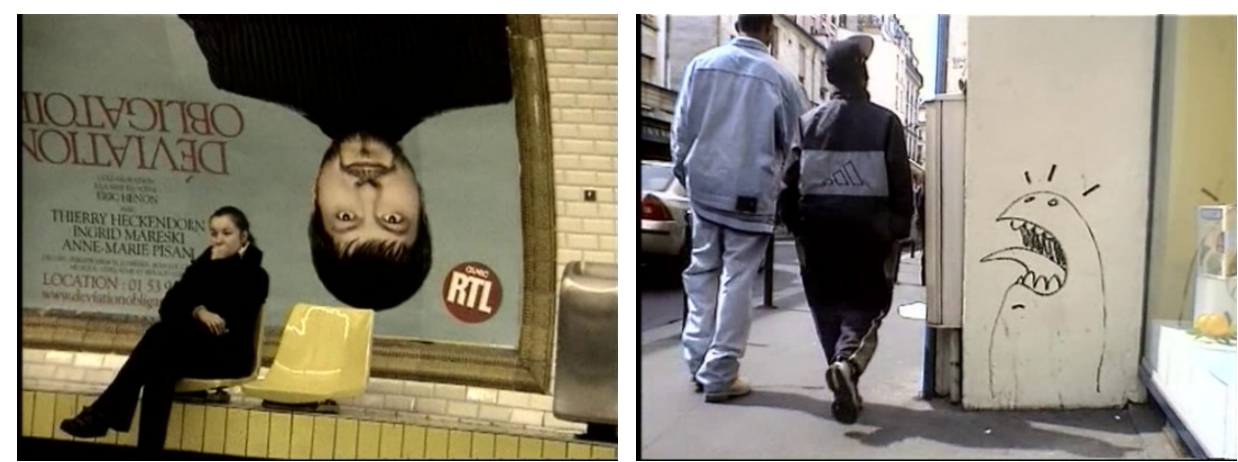

Marker "sempre foi atraído pelas inscrições nos muros, esses vestígios de uma passagem, sinais, como os amantes de La jetée, que se encontram através do tempo junto de 'seus sinais'” (GAUTHIER, 2011, p. 286). Aqui ele percorre qualquer canto da cidade à espreita de imagens, desenhos ou grafismos capazes de se tornarem imagens-signo e provocar o riso, a alfinetada ou a reflexão. Marker não apenas repensa ou recria o cinema-discurso de Eisenstein. Como este, o cineasta francês cultuava as colagens, ideogramas, haicais e rébus. Impossível nomear todos os achados que seu olho clínico apreende nessa floresta de design gráfico que é o mundo urbano.

No meio da campanha, dois cartazes da inventiva popular se singularizam: a) os cartazes de dois candidatos, homem e mulher, para a presidência e a vicepresidência, são sobrepostos em um outdoor intitulado La belle ou la bête; b) o slogan de um cartaz publicitário de uma motocicleta ("à esquerda, depois à direita, depois à esquerda, depois a direita...") dialoga com o pequeno cartaz de Jospin que fica abaixo e com o discurso off dele que acabamos de ouvir ("Sou socialista de inspiração, mas o projeto que proponho ao país não é um projeto socialista"). Em seguida, na montagem, um cartaz na rua pede o voto para Mounette, nome típico de gata, pois justamente se convida a falar sem subterfúgios ("En politique, il faut appeler un chat un chat. Votez Mounette"). Este engenhoso jeu de mots não poderia encontrar melhor sede que no filme de Marker, afinando o sentido literal (chamar um gato de um gato) e figurado da expressão (em política, devemos chamar as coisas pelo seu nome).

Dossiê A Música e suas Determinações Materiais - https://revistaecopos.eco.ufri.br/

ISSN 2175-8689 - v. 23, n. 1, 2020

DOI: 10.29146/eco-pos.v23i1.27549 


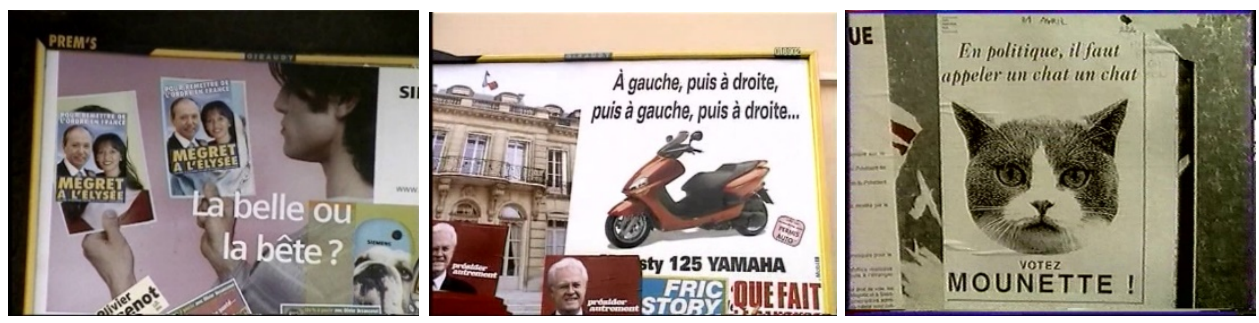

Brincando com a palavra cat-ástrofe, Marker coloca a cartela "le 21 avril, catastrophe", que sinaliza o resultado do primeiro turno das eleições presidenciais francesas vencido pelos candidatos Chirac e Le Pen, entre duas pequenas cenas dos gatos reais: a gata Caroline, que subiu no alto de uma árvore da rua Orléans e foi resgatada por um "jovem herói”, dado que "os bombeiros desistiram", e o gato Boléro do metrô, que "teve sua pata presa na escada rolante". As imagens da atadura e dos afagos da dona, como é habitual em Marker com os episódios significativos do cotidiano, ponderam-se em slow motion. Na sequência, um comentário de Marker dá início ao pequeno bloco do segundo turno: "E como as desgraças nunca vêm sozinhas".

Marker, brincando sério, diz que "a surpresa do segundo turno não foi a de Le Pen" (com 17,79 \% dos votos ${ }^{20}$ ), mas a entrada de M. Chat nas imagens do telejornal das 20h da TF1 (Televisão Francesa 1), marcada pela ambiguidade entre fato e apropriação: “Assim, o próprio Chat escolheu fazer sua volta”. Nesse momento, o apresentador pede conexão com o repórter sobre a "manifestação da extremaesquerda na Praça da Bastilha", cujas imagens ao vivo aparecem na tela do estúdio. É a primeira vez que é mostrado o desenho nos protestos nas ruas, como se o dispositivo do filme estivesse aguardando por isso. E o fato de ele aparecer em uma grande mídia (apresentada pela âncora Patrick Poivre d'Arvor, conhecido pelo acrônimo PPDA), líder de audiências e de nítida orientação de direita, é celebrado por Marker por meio de um longo fade out exceto para o pequeno círculo do manifestante com a faixa de M. Chat junto com a palavra Liberté. E, logo a seguir,

$20 \mathrm{O}$ avanço dos partidos nacionalistas e populistas de extrema-direita vem ocorrendo no mundo todo. Na França, Marine Le Pen alcançou 33,90\% contra 66,10\% dos votos de E. Macron nas eleições presidenciais de 2017. Em maio de 2019, ela venceu as eleições europeias - que já havia ganho em 2014 -, conquistando entre 23 e $24 \%$. 
“criando" um partido com o acrônimo CHAT, apresentado por seu alter ego Guillaume-en-Égypte, que aparece abraçando um cartaz de M. CHAT: “Confederação Humanista e Anarquista de Trabalhadores"21.

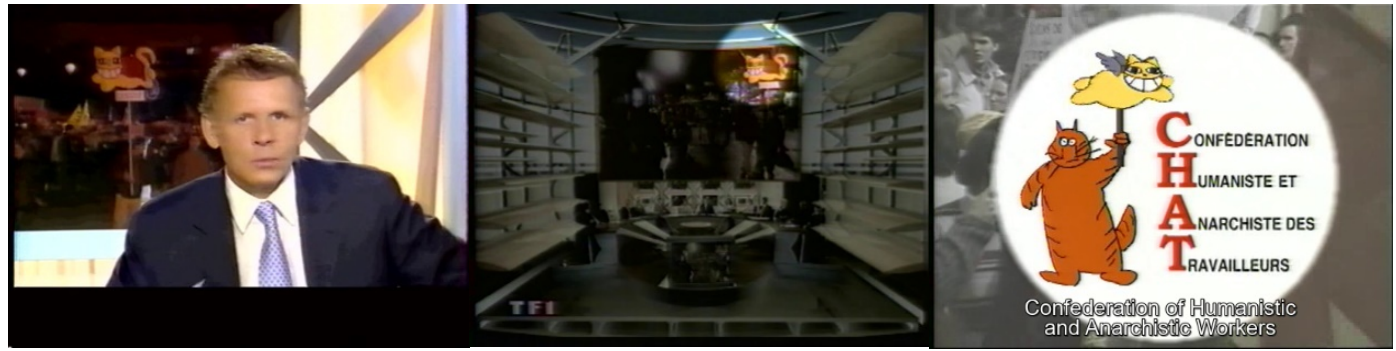

Marker segue então o rastro dos gatos nas manifestações, agora especialmente dominadas pelo clima de oposição à guerra do Iraque. "Cadê os gatos?" (Où sont les Chats?"), pergunta repetidas vezes. Se eles têm "ambições políticas", há de haver uma resposta aos "muros" nos "paralelepípedos" da cidade. Desta vez, sim, a reaparição dos M. Chats nas ruas, em uma manifestação dos americanos - em Paris - contra a guerra do Iraque, será celebrada em sequência isolada e música mirabolante de instrumentos de sopro, como de parada. As imagens iniciais em branco e preto, fora de foco, dão um tom fantasmático ao retorno dos felinos ao espaço político da vida pública. Os cartazes e máscaras do $\mathrm{M}$. Chat vão inundando a tela, agora em cores, e um deles se destaca: "Faites des chats, pas la guerre!!!"22.

\footnotetext{
21 Para Massart, as imagens do telejornal são "voluntariamente truncadas" por Marker, "arrastando o espectador para o lúdico". De acordo com o depoimento de Marker, ele correu ao metrô para se juntar à manifestacão na Bastilha logo que viu o felino no telejornal. Não conseguiu chegar, mas na estacão do metrô se juntou com um casal com a faixa do M. Chat: "Uma jovem, curiosa, aproximou-se, interessada [sobre o significado do termo CHAT da faixa]. Eu lhe disse: "Mas claro, é a Confederação Humanista e Anarquista dos Trabalhadores. E ela estava, sim, pronta a aderir". Marker acrescenta que "não procurou saber das intenções do grupo de 'irredutíveis' que se reuniram na Praça da Bastilha sob o emblema do gato, mas que lhe agrada este grupo de 'desorganizados biológicos' para os quais até mesmo os partidos da esquerda radical são institucionalizados demais e se recusam a ser assimilados. Por isso, não há encarnação mais pertinente que o Chat, o único ser do mundo que desde tempos imemoriais conquistou seu lugar no primeiro plano da vida cotidiana, da imagem, do sentimento e da mitologia sem nunca ter sido assimilado". "Chris Marker e M. Chat: chats discutent". Cf. Liberation, 4 de dezembro de 2004

22 "Faça um bate-papo, não faça guerra". Em outro momento, Marker brinca com a confusão no Google entre esses dois sentidos de "chat". 0 filme todo aborda com naturalidade e senso crítico as novas ferramentas digitais que, na época, estavam sendo introduzidas de forma maciça.
}

Dossiê A Música e suas Determinações Materiais - https://revistaecopos.eco.ufrj.br/

ISSN 2175-8689 - v. 23, n. 1, 2020

DOI: 10.29146/eco-pos.v23i1.27549 


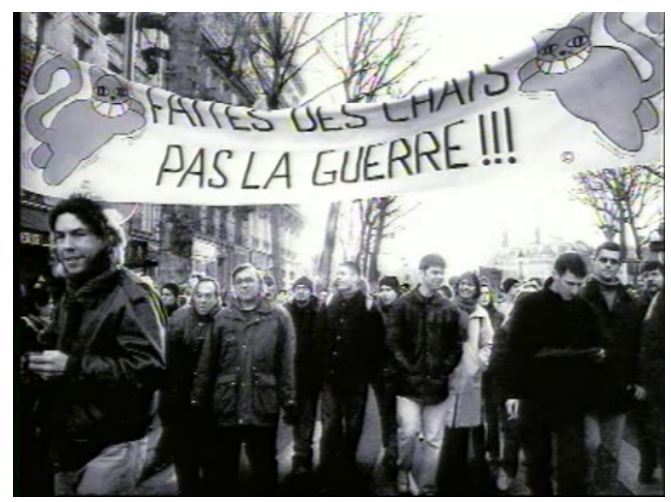

A partir das eleições presidenciais, o primeiro de maio e a guerra do Iraque, a escalada de protestos e eventos urbanos cresce de modo exponencial, sem que o filme perca, no entanto, o tom descontraído e leve: decepção com o governo Raffarin, greve geral (com referência às lutas dos anos trinta e sessenta e breve - mas entusiástica - citação de Greve, 1925, de S. Eisenstein), aposentadoria, happening contra a AIDS em torno da torre Eiffel23, crítica ao "povo que se reúne para ver onze milionários batendo uma bola" na Copa de 2002 e às "dimensões stalinistas" de suas fotografias na cidade, ato contra os "morts de la rue" (acidentes, mendigos etc.), trabalho temporário do pessoal das artes e espetáculos, manifestações das mulheres muçulmanas a favor do véu, dos tibetanos contra a China, dos liberais de direita contra os grevistas, dos movimentos sociais contra a prisão do ativista José Bové.

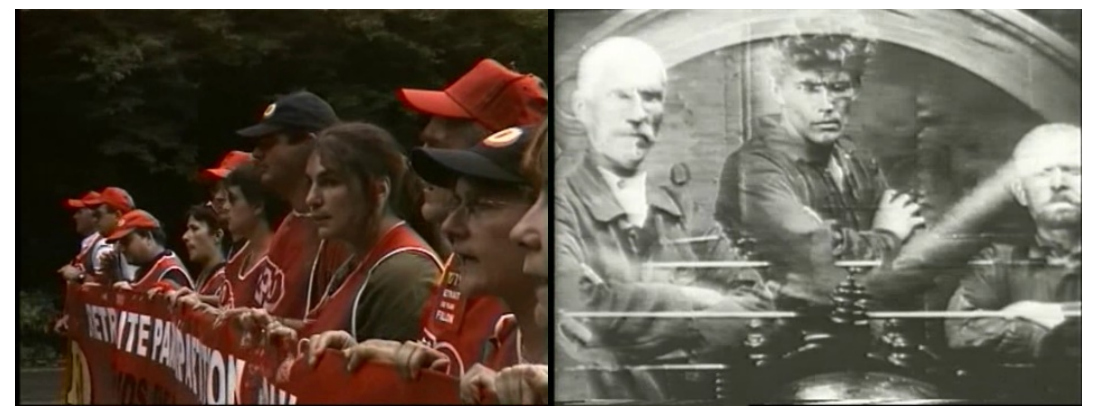

23 A torre Eiffel, lugar onde foi lançado o primeiro sinal horário mundial (01/07/1913), apresenta agora um grande painel eletrônico para lembrar, em tempo real, o "número de vítimas da AIDS" (01/06/2003). Marker, retomando a chave estética de La jetée, mostra os participantes deitados em um cenário apocalíptico pontuado pela música e as lentas fusões de imagens estáticas em preto e branco.

Dossiê A Música e suas Determinações Materiais - https://revistaecopos.eco.ufrj.br/

ISSN 2175-8689 - v. 23, n. 1, 2020

DOI: 10.29146/eco-pos.v23i1.27549 
Tudo isso acontece num momento em que M. Chat, após seu "triunfo na grande manifestação" contra a guerra do Iraque, decidiu "descansar ou desaparecer". Embora seu prestígio não pare de crescer em outros lugares (Nantes, Tours, Île de Ré, Zurique), Marker parece perceber que "os paralelepípedos parisienses não lhe interessam mais". 0 tom melancólico que o último terço do filme vai adotando é sinalizado pela cabeça de um gato que, desde o céu - em fusão com as nuvens -, nos observa pesaroso. Desta vez, ele não sorri; ele não é amarelado ou alaranjado, mas de cor preta e sem as pequenas asas brancas.

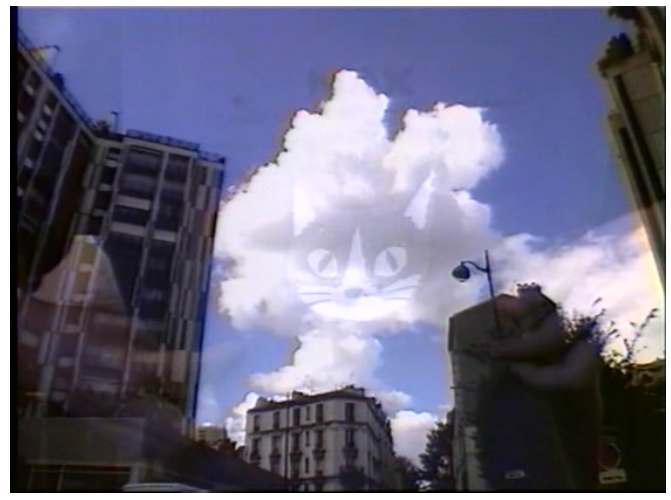

\section{Conclusão: os gatos que desaparecem e o uivo do lobo}

0 relato de Marker dos protestos em Paris no agitado biênio depois de setembro de 2001 se encerra com os funerais, em 2003, de duas personalidades: o do professor e oncologista Léon Schwartzenberg, morto aos 79 anos, que "havia sempre defendido os imigrantes ilegais", e o da atriz Marie Trintignant, morta aos 41 anos, depois de sofrer um edema cerebral em decorrência dos espancamentos desferidos pelo namorado, o cantor da banda Noir Désir Bertrand Cantat, em Vilnius, capital da Lituânia.

A opção do autor por este tipo de desfecho implica uma confluência de elementos simbólicos: a morte e o rito funerário, a passagem do sujeito coletivo ao individual, a convergência de questões abertas e desconexas ao longo do filme, como os imigrantes ilegais e as mulheres. Porém, o elemento primordial é que o autor se 
serve de sua própria experiência para conectar esses dois acontecimentos funestos que fazem o arremate, aparentemente aleatório, da cadeia de protestos: $a$ última vez que vi Schwartzenberg (nos protestos pela liberdade de José Bové), a primeira vez que vi Cantat (via flashback, em show de 1999 em favor dos imigrantes ilegais).

O metrô é de novo o palco da experiência coletiva, não mais dos efeitos da beligerante geopolítica nos cidadãos, mas da violência no cotidiano. De novo é ativada para valer a arte markeriana da justaposição e da fulguração de sinais, agora em um tom intimista de pesadelo. Por cima das imagens em preto e branco de rostos de passageiros desconhecidos, como se tivessem sido surpreendidos em trens e viagens (ao fim) da noite ${ }^{24}$, são sobrepostas imagens ligadas à tragédia, breves lampejos dos rostos dos protagonistas e manchetes de revistas onde faíscam palavras-chave como Trintignant, tragédie, Cantat, Vilnius, Noir Désir etc. A tristeza e o pessimismo se instalam no filme ao compasso das texturas "fraturadas" da música eletrônica: "Não é estranho que os gatos nos abandonem". Na volta à estação de metrô do gato Boléro, constata-se o seu desaparecimento: "E se eles nos deixaram definitivamente?". Na sequência, Marker mostra vários desenhos que desapareceram da cidade.

Os gatos agora falam por si mesmos nas cartelas do autor: "Nós somos os Chats da liberdade. Se vocês não nos compreendem, vocês terão que se virar sozinhos". Um novo desenho dos gatos no pavimento da rua, agora formando um grupo em círculo, traz "então" um "sinal" para Marker, termo que destaca, como já fizera na primeira aparição do M. Chat, em letras maiúsculas: "Et puis - UN SIGNE”. $\mathrm{Na}$ verdade, um duplo sinal: por um lado, o enigmático desenho é utilizado, em primeiro lugar e de modo antecipatório, como uma espécie de halo no rosto de um jovem estrangeiro do metrô; por outro, o lugar na rua onde aparece esse misterioso desenho. Quanto ao desenho da rua, Marker o interpreta da seguinte forma: "Rondas de gatos nos cantos das ruas para velar o sono dos moradores". Ele agradece aos gatos ("precisamos muito de vocês"), vê a cidade e a vida dos humanos sem nenhum

24 Embora o tom onírico seja completamente diferente, lembra as viagens de trem, no Japão, de Sans Soleil, e o ensaio fotográfico (com textos do autor) Le Dépays, ambos de 1982. Nesses trabalhos, Marker se diverte em imaginar os sonhos dos passageiros, adormecidos, com imagens da televisão ou de filmes de terror japoneses.

Dossiê A Música e suas Determinações Materiais - https://revistaecopos.eco.ufri.br/ 
sentido. Mostra sucessivas elipses no plano fixo de um cruzamento de ruas onde pessoas e veículos aparecem e desaparecem como traço característico de ir à deriva nas cidades, enquanto o cerimonioso desenho circular, em primeiro termo, é a única coisa que permanece no espaço-tempo. Sumiram os desenhos dos gatos nos muros, tetos e árvores da cidade (emblemas e/ou prefigurações da alegria, da revolta, da utopia), mas do nada aparece outro no chão com o ar criptográfico de um hieróglifo ou de uma estela funerária (e também, é forçoso dizer, com a singeleza infantil de um clássico do desenho animado). É evidente que este desenho, em suas duas variantes, é o instante decisivo no acontecer figural dos gatos.
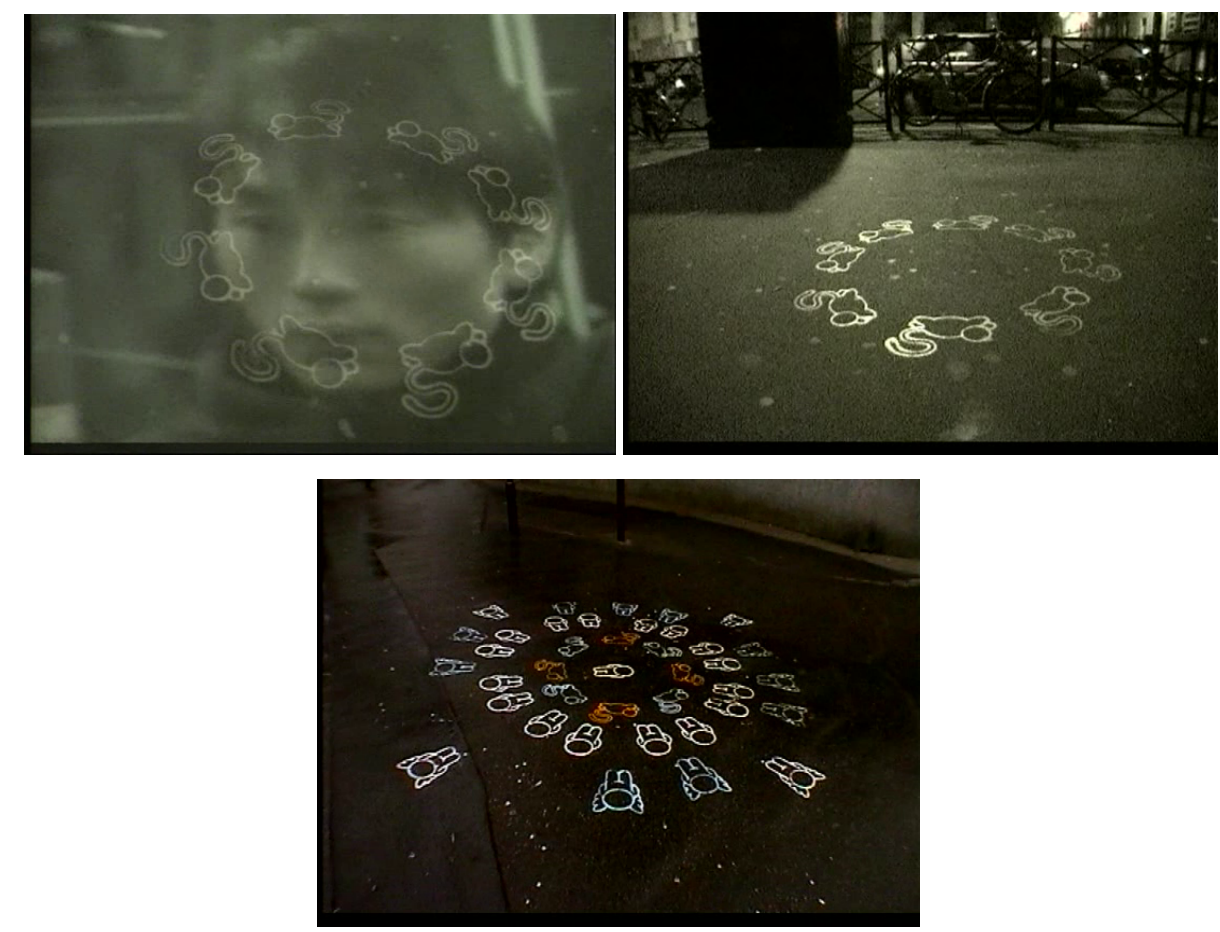

O novo desenho dos gatos dá uma ideia de singeleza, circularidade, eterno retorno. A mesma figura - um gato branco, de perfil, saltitante - se repete oito vezes formando um círculo perfeito. Em uma variante deste desenho que aparece em outra rua, estes grafismos repetidos alternam a cor branca e a laranja. Por volta do círculo dos gatos, figuras humanas ou humanoides acabam formando, por sua vez, um novo círculo. Elas aparecem vistas de cima e parecem cadeirantes ou astronautas. Uma dessas pequenas figuras humanas está no interior do círculo dos gatos, como a 
sugerir que são acolhedores. 0 último círculo ainda está se formando com a chegada de novas figuras. Elas são uma variante da anterior, pois em lugar de braços parecem ter asas. Assim sendo, os círculos são compostos por animais, humanos e anjos. As figuras humanas e espirituais se sentem atraídas e param para observar a brincadeira dos gatos, repetindo seu modelo de palco circular. Isto é, a harmonização entre imanência e transcendência, entre contingência e eternidade, entre arte (e/ou política) e religião (e/ou mito) é feita a partir do elemento animal: o felino (brincalhão) que dá pulos
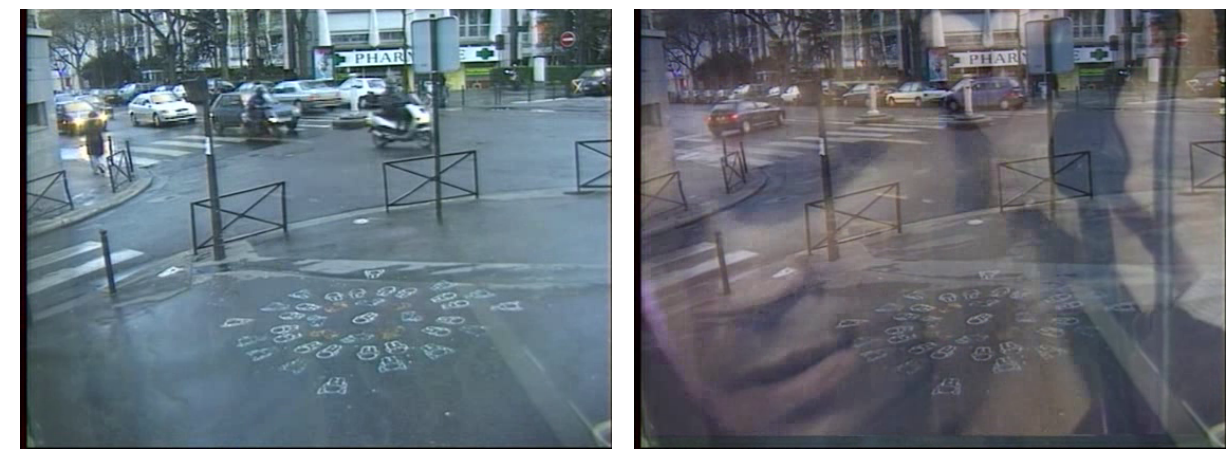

O filme termina com uma lacônica lenda e com o retorno do close de Bertrand Cantat cantando no show (de novo desprovido de som, o que se entende como uma forte recriminação). 0 rosto do cantor é contrastado com o do jovem asiático mostrado pouco antes. Este jovem tem um olhar singular, que transmite inteligência e inocência, e talvez temor, capturado em uma espécie de "momento decisivo" pela camcorder de Marker no interior do metrô. $\mathrm{O}$ fato de mostrar o rosto do jovem asiático fusionado com o arcano pictograma dos felinos girando em sentido horário é toda uma declaração de intenções da parte de Marker. 0 filme inteiro está preocupado em mostrar, com o mesmo calor que sente pelos gatos, um horizonte de coexistência com pessoas vindas de todos os cantos do mundo numa grande cidade europeia. Mas, diferentemente do jogo do pega-pega (chat perché), em que os papéis de lobo e gato podem ser reversíveis quando a criança é pega, na difícil convivência na pólis há também o sentido que costumamos dar ao uivo do lobo conforme a lenda que encerra o filme:

Dossiê A Música e suas Determinações Materiais - https://revistaecopos.eco.ufri.br/ 
"Uma velha lenda conta que o duque Gediminas, criador da cidade de Vilnius, sonhou com um lobo uivando em uma colina. Um padre, na época, interpretou o sonho como segue: teria de construir uma cidade da qual se ouviria falar no mundo todo como se ouve o lobo uivar"25.

A melancolia com a qual finaliza o filme não decorre do fracasso de um projeto emancipador que marcou indelevelmente o século XX - não obstante seus ideais, de alguma forma ou de outra, continuarem vigentes, tal como revelam as pessoas, em Chats perchés, na hora de se indignar ou de exigir direitos no espaço público. É uma outra melancolia, causada por certas formas e explosões de violência - interpretações do mundo que são sintomatologias do medo, como bem diz a lenda lituana, cujo sentido, ou imagem, não poderia ser mais hobbesiana - que Marker auscultou em sua crônica ensaística do início do milênio e que foram se agravando ao longo das duas últimas décadas: o auge de todos os extremismos e fundamentalismos, do populismo, da violência contra a mulher e contra os imigrantes, da xenofobia, do racismo, da aporofobia. Somos animais cada vez menos políticos e cada vez mais medrosos. Dado que seu estar no mundo (com os outros) é aparecer e desaparecer, o filme parece mitigar seu sad ending confiando que sempre haverá novos sinais a serem emitidos por alguns gatos insubmissos e cosmopolitas, não sabemos se pendurados como o próprio cinema.

\section{Referências bibliográficas}

ASTRUC, A. "Nascimento de uma nova vanguarda: a caméra-stylo". (Artigo original: L'écran français n. 144, 30 de março de 1948). Traduzido por Matheus Cartaxo. Disponível em: http://www.focorevistadecinema.com.br/FOCO4/stylo.htm. Acesso em 4 de abril de 2019.

25 No final da cartela, Marker indica data e fonte, proveniente do escritor lituano "Marius Ivaskevicius" e do semanário francês "Courrier Internacional de 19 junho de 2003". Na noite de 26 a 27 de julho de 2003, Marie Trintignant, filha de Jean-Louis Trintignant, foi espancada pelo namorado em um hotel de Vilnius, onde rodava o telefilme Colette, une femme libre. No dia 31 de julho, foi repatriada à França em estado de morte cerebral. Morreu no dia seguinte, $1^{\circ}$ de agosto de 2003. Ver https://fr.wikipedia.org/wiki/Marie Trintignant

\section{Dossiê A Música e suas Determinações Materiais - https://revistaecopos.eco.ufrj.br/}


AUERBACH, Erich. Mímesis. La representación de la realidad en la literatura occidental. México: FCE, 1996.

Figura. Madri: Trotta, 1998.

AZÚA, Félix. Diccionario de las artes. Barcelona: Planeta, 1995.

BELLOUR, Raymond. «Chris Marker». In: Planète Marker. Le guide. 16 octobre - 22 décembre. Catálogo do Centre Pompidou, Paris, 2013.

BENJAMIN, Walter. Obras, Libro IV, vol 1. (Imagénes que piensan). Madri: Abada, 2010.

BURCH, Noel. Práxis do cinema. São Paulo: Perspectiva, 1969.

CASETTI, Francesco. Eye of the Century. Film, Experience, Modernity. Nova York: Columbia University Press, 2008.

CUNHA, Norberto Ferreira da. "A arte do ensaio: a vocação socrática de Proteu". Revista de História das Ideias, vol. 32, 2011, pp. 569-598. Disponível em: https://digitalisdsp.uc.pt/ispui/handle/10316.2/41405 Acesso em 22 de maio de 2019.

Dicionário Priberam da língua portuguesa. Lisboa: Priberam. Disponível em: http://www.priberam.pt/DLPO/digital Acesso em18 de abril de 2019.

DITTMAR, J. "Baisers de Paris. Chats Perchés - Chris Marker". Disponível em: http://www.comprendre-

agir.org/images/fichierdyn/resume/2007/chats perches chris marker fluctuatnet chsct. pdf Acesso em 23 de março de 2019.

ECHEVARRÍA, Javier. Telépolis, Barcelona: Destino, 1994.

FLINN, Margaret C. "Signs of the times: Chris Marker's Chats Perchés". Yale French Studies, $\mathrm{n}$ 115, New Spaces for French and Francophone Cinema, 2009, pp. 93-111. Disponível em: http://www.jstor.org/stable/25679757 Acesso em 9 de maio de 2019.

GARCÍA GUAL, Carlos. Diccionario de mitos. Madri: Siglo XXI, 2003.

GAUTHIER, Guy. "Le fond de l'air est chat". Jeune Cinéma, Montreuil, n² 293, dezembro 2004. Disponível em: http://www.jeunecinema.fr/spip.php?article120 Acesso em 12 de março de 2019.

O documentário: um outro cinema. Campinas: Papirus, 2011.

MARKER, Chris. «Le seconde vie de Chris Marker», entrevista aos jornalistas Julien Gester e Serge Kaganski, Les Inrocks, Paris, n. 648, 29 abril 2008. Disponível em: http://www.lesinrocks.com/2008/04/29/cinema/la-seconde-vie-de-chris-marker$1151546 /$ Acesso em 7 de abril de 2019.

Dossiê A Música e suas Determinações Materiais - https://revistaecopos.eco.ufrj.br/

ISSN 2175-8689 - v. 23, n. 1, 2020

DOI: 10.29146/eco-pos.v23i1.27549 
«Chris Marker e M. Chat: chats discutent», Entrevista entre C. Marker e ThomaVuillon (autor dos desenhos M. Chat), Liberation, Paris, 4 dezembro 2004. Disponível em: http://next.liberation.fr/arts/2004/12/04/chats-discutent 501770 Acesso em 5 de maio de 2019.

Roteiro de Chat Perchés. http://chrismarker.ch/ media/bv000035.lkdoc.chatsperches-ch2-2013.pdf

LANCEROS, Patxi. El robo del futuro. Fronteras, miedos, crisis. Madri: Catarata, 2017.

MASSART, Guillaume. «Chats Perchés» (Resenha do DVD). Film de Culte. Disponível em: http://archive.filmdeculte.com/video/video.php?id=277 Acesso em 14 de março de 2019.

PARVOULI, Bamchade et al. Planète Marker. Le guide. Du 16 octobre au 22 décembre. Paris: Centre

http://mediation.centrepompidou.fr/education/ressources/ENS-chrismarker/ Acesso em 8 de maio de 2019. 